\title{
GATA1 mutations in a cohort of Malaysian children with Down syndrome-associated myeloid disorder
}

\author{
Su Han $\underline{\text { Lum }}^{1}$, MMed, Soo Sin $\underline{\text { Choong }}^{1}$, BSc, Shekhar $\underline{\text { Krishnan }}^{1,2}$, PhD, Zulqarnain Mohamed ${ }^{3}$, PhD, Hany $\underline{\text { Ariffin }}^{1,2}$, PhD
}

\begin{abstract}
INTRODUCTION Children with Down syndrome (DS) are at increased risk of developing distinctive clonal myeloid disorders, including transient abnormal myelopoiesis (TAM) and myeloid leukaemia of DS (ML-DS). TAM connotes a spontaneously resolving congenital myeloproliferative state observed in $10 \%-20 \%$ of DS newborns. Following varying intervals of apparent remission, a proportion of children with TAM progress to develop ML-DS in early childhood. Therefore, TAM and ML-DS represent a biological continuum. Both disorders are characterised by recurring truncating somatic mutations of the GATA1 gene, which are considered key pathogenetic events.

METHODS We herein report, to our knowledge, the first observation on the frequency and nature of GATA1 gene mutations in a cohort of Malaysian children with DS-associated TAM $(n=9)$ and ML-DS $(n=24)$ encountered successively over a period of five years at a national referral centre.

RESULTS Of the 29 patients who underwent GATA1 analysis, GATA1 mutations were observed in 15 (51.7\%) patients, including $6(75.0 \%)$ out of 8 patients with TAM, and $9(42.9 \%)$ of 21 patients with ML-DS. All identified mutations were located in exon 2 and the majority were sequence-terminating insertions or deletions (66.7\%), including several hitherto unreported mutations (12 out of 15).

CONCLUSION The low frequency of GATA1 mutations in ML-DS patients is unusual and potentially indicates distinctive genomic events in our patient cohort.
\end{abstract}

Keywords: Down syndrome, GATA1, ML-DS, TAM

\section{INTRODUCTION}

Down syndrome (DS) is the most common congenital cytogenetic abnormality, with an incidence of one in 600-800 live births. ${ }^{(1}$ The syndrome is characterised by recognisable physical features, cognitive disability, and a varying frequency of cardiac, gastrointestinal, skeletal and endocrine defects. DS is also characterised by an increased susceptibility to childhood leukaemia, ${ }^{(2-4)}$ including an increased frequency of distinctive clonal myeloid disorders in early childhood. A spontaneously resolving congenital myeloproliferative state designated as transient abnormal myelopoiesis (TAM) is encountered in 10\%-20\% of DS newborns. ${ }^{(5)}$ After a period of apparent remission (1-4 years), $20 \%-30 \%$ of DS children with TAM progress to develop a characteristic, treatment-responsive megakaryoblastic form of acute myeloid leukaemia termed myeloid leukaemia of DS (ML-DS). ${ }^{(6,7)}$

TAM and ML-DS thus represent a continuum of clonal myeloproliferation in DS. Fundamental to both disorders is the gene-dosage imbalance of the human chromosome $21 .^{(8)}$ An additional shared, critical pathogenetic event involves the acquisition of characteristic somatic mutations in the GATA1 gene. ${ }^{(9)}$ The gene, located on chromosome X (Xp11.23), encodes a key haematopoietic transcription factor involved in erythroid and megakaryocyte differentiation. These mutations, involving exons 2 or 3 of the GATA1 gene, result in synthesis of an aberrant truncated isoform (termed short GATA1 or GATA1s) that is putatively oncogenic. ${ }^{(10)}$ The mechanistic basis for somatic GATA1 mutations and the additional molecular events that determine progression from TAM to ML-DS are the focus of intense research. ${ }^{(11,12)}$

This observational study attempts to characterise, for the first time, to our knowledge, the frequency and nature of somatic GATA 1 mutations in DS children with TAM and ML-DS, encountered consecutively over a period of five years at a national paediatric oncology referral centre in Malaysia.

\section{METHODS}

From January 2007 to December 2011, children with DS who were consecutively diagnosed to have TAM and/or ML-DS at University Malaya Medical Centre, Kuala Lumpur, Malaysia, were included in the study. The diagnosis of TAM was based on observation of unequivocal blasts on peripheral blood microscopy. ML-DS was confirmed by marrow studies, including microscopy, flow cytometry and, where indicated, bone marrow histology. Parental consent was obtained in all cases. Institutional approval was granted to collect, store and study peripheral blood and/or bone marrow samples from children in the study (University of Malaya Ethical Approval Reference MEC 2008/678.13). Clinical and laboratory data were retrieved from patient medical records.

Mononuclear cells were isolated from peripheral blood (TAM) and bone marrow (ML-DS) by erythrocyte lysis, followed by serial centrifugation. Genomic DNA was extracted from mononuclear cells using standard chloroform-phenol isolation. Screening for GATA1 mutations was carried out by selective stepwise analysis of exons 2 and 3, with exon 3 sequences analysed in samples

${ }^{1}$ Department of Paediatrics, University Malaya Medical Centre, ${ }^{2}$ University Malaya Cancer Research Institute, Faculty of Medicine, ${ }^{3}$ Unit of Genetics and Molecular Biology, Institute of Biological Sciences, Faculty of Science, University of Malaya, Kuala Lumpur, Malaysia

Correspondence: Dr Su Han Lum, Clinical Specialist, Department of Paediatrics, University Malaya Medical Centre, 50630 Kuala Lumpur, Malaysia. suhanlum@gmail.com 
Table I. Clinical characteristics and laboratory data of the transient abnormal myelopoiesis (TAM) patients $(n=9)$.

\begin{tabular}{|c|c|}
\hline Parameter & $\begin{array}{c}\text { No. (\%)/ } \\
\text { Median (range) }\end{array}$ \\
\hline \multicolumn{2}{|l|}{ Gender } \\
\hline Male & $6(66.7)$ \\
\hline Female & $3(33.3)$ \\
\hline Gestation age (wk) & $38(32-40)$ \\
\hline Birth weight (kg) & $2.73(1.80-3.10)$ \\
\hline Age at diagnosis (day) & $1(0-15)$ \\
\hline \multicolumn{2}{|l|}{ Clinical signs } \\
\hline Liver size $(\mathrm{cm})$ & $4(0-5)$ \\
\hline Spleen size $(\mathrm{cm})$ & $2(0-4)$ \\
\hline \multicolumn{2}{|l|}{ Diagnostic laboratory examination } \\
\hline White blood cell ( $\left.\times 10^{9} / \mathrm{L}\right)$ & $41.8(13.0-308.8)$ \\
\hline Blast $(\%)$ & $25(1-79)$ \\
\hline Haemoglobin $(\mathrm{g} / \mathrm{dL})$ & $13.4(7.9-22.7)$ \\
\hline Platelet $\left(\times 10^{9} / \mathrm{L}\right)$ & $127(71-546)$ \\
\hline Aspartate aminotransferase (IU/L) & $43(18-197)$ \\
\hline Alanine aminotransferase (IU/L) & $75(17-357)$ \\
\hline Follow-up (mth) & $14(6-47)$ \\
\hline Time to TAM resolution (day) & $46(21-188)$ \\
\hline \multicolumn{2}{|l|}{ Treatment } \\
\hline Yes & $3(33.3)$ \\
\hline No & $6(66.7)$ \\
\hline \multicolumn{2}{|l|}{ Outcome } \\
\hline Remission & $7(77.8)$ \\
\hline Progressed to ML-DS & $1(11.1)$ \\
\hline Death & $1(11.1)$ \\
\hline
\end{tabular}

ML-DS: myeloid leukaemia of Down syndrome

bearing wild-type exon 2. The exon 2 sequence was amplified using primers (forward 5'-GGAAGGATTTCTGTGTCTGAG-3' and reverse 5'-GCACTCAGCCAATGCCAAGA-3') and polymerase chain reaction (PCR) cycling conditions reported by Rainis et al. ${ }^{(13)}$ Exon 3 segments were amplified using primers (forward 5'-GCACTCAGCCAATGCCAAGA-3' and reverse 5'-GAGCTAGGCTCAGCTCAGCTTTAC-3') and PCR cycling conditions reported by Nichols et al. ${ }^{(14)}$ All PCR reactions were carried out in $25 \mu \mathrm{L}$ volumes using the HotStarTaq DNA Polymerase (QIAGEN, Hilden, Germany). PCR products were processed using the QIAquick PCR Purification Kit (QIAGEN, Hilden, Germany) to remove reaction residuals and subjected to automated nucleotide sequencing (Applied Biosystems ABI 3730XL; Thermo Fisher Scientific, Waltham, Massachusetts, USA). PCR amplification was tested with an adequate number of controls. Sequence analysis was performed using the online opensource BioEdit sequence alignment tool (version 7.0.1); the NCBI GATA1 sequence NG_008846.1 served as a reference sequence. All sequence variations and predicted amino acid changes were categorised according to nomenclature recommendations from the Human Genome Variation Society (HGVS). ${ }^{(15)}$

\section{RESULTS}

A total of 33 patients with DS-associated myeloid disorders were encountered over the duration of the study, consisting
Table II. Clinical characteristics and laboratory data of the myeloid leukaemia of Down syndrome (ML-DS) patients $(n=24)$.

\begin{tabular}{|c|c|}
\hline Parameter & $\begin{array}{c}\text { No. }(\%) / \\
\text { Median (range) }\end{array}$ \\
\hline \multicolumn{2}{|l|}{ Gender } \\
\hline Male & $10(41.7)$ \\
\hline Female & $14(58.3)$ \\
\hline History of TAM & $2(8.3)$ \\
\hline History of myelodysplastic phase & $6(25.0)$ \\
\hline Age at diagnosis (mth) & $24(10-60)$ \\
\hline \multicolumn{2}{|l|}{ Presenting symptom* } \\
\hline Fever & $17(70.8)$ \\
\hline Pallor & $18(75.0)$ \\
\hline Bleeding & $11(45.8)$ \\
\hline \multicolumn{2}{|l|}{ Clinical signs } \\
\hline Liver size $(\mathrm{cm})$ & $3(0-9)$ \\
\hline Spleen size $(\mathrm{cm})$ & $1(0-10)$ \\
\hline Lymphadenopathy & $5(20.8)$ \\
\hline \multicolumn{2}{|l|}{ Diagnostic laboratory examination } \\
\hline White blood cell (× 109/L) & $9.5(4.4-200.0)$ \\
\hline Blast (\%) & $16(0-93)$ \\
\hline Haemoglobin (g/dL) & $7.1(3.8-12.4)$ \\
\hline Platelet $\left(\times 10^{9} / \mathrm{L}\right)$ & $25(5-936)$ \\
\hline Aspartate aminotransferase (IU/L) & $36(14-98)$ \\
\hline Alanine aminotransferase (IU/L) & $50(22-159)$ \\
\hline Bone marrow blast (\%) & $42(10-75)$ \\
\hline CNS disease & 0 \\
\hline \multicolumn{2}{|l|}{ Treatment } \\
\hline Yes & $22(91.7)$ \\
\hline No & $2(8.3)$ \\
\hline Follow-up (mth) & $11(0.1-55.0)$ \\
\hline \multicolumn{2}{|l|}{ Outcome } \\
\hline Remission & $14(58.3)$ \\
\hline Died & $9(37.5)$ \\
\hline Resistant disease & $2(8.3)$ \\
\hline Relapse & $4(16.7)$ \\
\hline Sepsis & $3(12.5)$ \\
\hline Defaulted & $1(4.2)$ \\
\hline
\end{tabular}

*Patients may have presented with $\geq 1$ symptom. No ML-DS patients had central nervous system (CNS) leukaemia. TAM: transient abnormal myelopoiesis

of nine patients with TAM and 24 patients with ML-DS. Their clinical characteristics and laboratory data are summarised in Tables I and II. TAM was diagnosed at a median age of one day; five patients were diagnosed at birth. Detection of TAM was incidental in the majority $(n=7)$ and occurred in the course of blood testing for other conditions (jaundice, respiratory distress and bowel obstruction). One newborn was ill with hydrops fetalis, while the other developed self-limited pericardial effusion in utero. Three of the nine newborns required medical intervention, including intravenous cytarabine in one newborn to treat significant splenomegaly, exchange transfusion for another newborn with hydrops fetalis, and intermittent transfusion for another with symptomatic anaemia and thrombocytopenia. The newborn with hydrops fetalis developed refractory hepatic failure and died on Day 9 of life. Median time to TAM resolution was 
Table III. Characteristics of GATA1 mutations.

\begin{tabular}{|c|c|c|c|c|c|c|c|c|}
\hline Patient & $\begin{array}{c}\text { White } \\
\text { blood cell } \\
\left(\times 10^{9} / \mathrm{L}\right)\end{array}$ & $\begin{array}{c}\text { DNA } \\
\text { source } \\
\text { (blast [\%]) }\end{array}$ & DNA sequence change & $\begin{array}{l}\text { Amino acid } \\
\text { change }\end{array}$ & $\begin{array}{l}\text { Type of } \\
\text { mutation }\end{array}$ & $\begin{array}{l}\text { Predicted } \\
\text { consequence }\end{array}$ & $\begin{array}{l}\text { Outcome } \\
\text { (follow-up [mth]) }\end{array}$ & Remark \\
\hline TAM1 & 14.3 & PB (22) & c. $220 G>T$ & p.Val74Phe & $\begin{array}{l}\text { Missense at } \\
\text { exon } 2 \text { exon/ } \\
\text { intron boundary }\end{array}$ & Splicing error & ML-DS (19) & $\begin{array}{l}\text { Kanezaki } \\
\text { et al }\left.\right|^{(18)}\end{array}$ \\
\hline TAM3 & 13.0 & PB (26) & c. 105 _106insC & p.Ser36Leufs*4 & $\begin{array}{l}\text { Frameshift } \\
\text { insertion }\end{array}$ & $\begin{array}{l}\text { Premature } \\
\text { termination } \\
\text { codon }\end{array}$ & CCR (6) & $\begin{array}{l}\text { Novel } \\
\text { mutation }\end{array}$ \\
\hline TAM4 & 30.2 & PB (1) & c. 150 delG & p.Ser51Alafs*86 & $\begin{array}{l}\text { Frameshift } \\
\text { deletion }\end{array}$ & $\begin{array}{l}\text { Premature } \\
\text { termination } \\
\text { codon }\end{array}$ & CCR (19) & $\begin{array}{l}\text { Novel } \\
\text { mutation }\end{array}$ \\
\hline TAM5 & 308.8 & PB (79) & c. 5_14delAGTTCCCTGC & p.Glu2Ala & $\begin{array}{l}\text { Frameshift } \\
\text { deletion }\end{array}$ & Splicing error & $\begin{array}{l}\text { Died of hepatic } \\
\text { failure }(0.3)\end{array}$ & $\begin{array}{l}\text { Novel } \\
\text { mutation }\end{array}$ \\
\hline TAM6 & 65.6 & PB (NA) & c. $183 \_187$ delCTACT & p.Tyr62Glnfs*4 & $\begin{array}{l}\text { Frameshift } \\
\text { deletion }\end{array}$ & $\begin{array}{l}\text { Premature } \\
\text { termination } \\
\text { codon }\end{array}$ & CCR (31) & $\begin{array}{l}\text { Novel } \\
\text { mutation }\end{array}$ \\
\hline TAM7 & 66.7 & PB (55) & c. $216 \_219$ delCCCAinsTG & p.Pro73Gly & $\begin{array}{l}\text { Sequence } \\
\text { replacement }\end{array}$ & Splicing error & CCR (6) & $\begin{array}{l}\text { Novel } \\
\text { mutation }\end{array}$ \\
\hline ML-DS4 & 6.4 & BM (38) & c. 93_94delGG & p.Val33Phefs*7 & $\begin{array}{l}\text { Frameshift } \\
\text { deletion }\end{array}$ & $\begin{array}{l}\text { Premature } \\
\text { termination } \\
\text { codon }\end{array}$ & CCR (48) & $\begin{array}{l}\text { Novel } \\
\text { mutation }\end{array}$ \\
\hline ML-DS5 & 107.7 & BM (17) & c. $176 \_177$ insCAGGTGCG & p.Ala56GInfs*81 & $\begin{array}{l}\text { Frameshift } \\
\text { insertion }\end{array}$ & $\begin{array}{l}\text { Premature } \\
\text { termination } \\
\text { codon }\end{array}$ & $\begin{array}{l}\text { Relapse but CCR } \\
\text { after salvage } \\
\text { therapy (52) }\end{array}$ & $\begin{array}{l}\text { Novel } \\
\text { mutation }\end{array}$ \\
\hline ML-DS7 & 26.6 & BM (35) & c. $76 \_77$ delTC & p.Ser26Hisfs* 13 & $\begin{array}{l}\text { Frameshift } \\
\text { deletion }\end{array}$ & $\begin{array}{l}\text { Premature } \\
\text { termination } \\
\text { codon }\end{array}$ & CCR (42) & $\begin{array}{l}\text { Novel } \\
\text { mutation }\end{array}$ \\
\hline ML-DS9 & 12.9 & BM (60) & c. $-20 G>A$ & Splicing error & Missense & Splicing error & $\begin{array}{l}\text { Died of early } \\
\text { marrow } \\
\text { relapse (5) }\end{array}$ & $\begin{array}{l}\text { Novel } \\
\text { mutation }\end{array}$ \\
\hline ML-DS17 & 200 & $\mathrm{BM}(\mathrm{NA})$ & c. $222+3+4$ ins T & Splicing error & $\begin{array}{l}\text { Frameshift } \\
\text { insertion }\end{array}$ & Splicing error & $\begin{array}{l}\text { Died of resistant } \\
\text { disease (2) }\end{array}$ & $\begin{array}{l}\text { Novel } \\
\text { mutation }\end{array}$ \\
\hline ML-DS19 & 9.3 & $\mathrm{BM}(11)$ & c. $208_{-}+9$ del & p.Arg70lle & Deletion & Splicing error & $\begin{array}{l}\text { Died of } \\
\text { sepsis (2) }\end{array}$ & $\begin{array}{l}\text { Novel } \\
\text { mutation }\end{array}$ \\
\hline ML-DS22 & 8.64 & BM (15) & c. $187 \_188$ ins T & p.Tyr63Leufs*5 & $\begin{array}{l}\text { Frameshift } \\
\text { insertion }\end{array}$ & $\begin{array}{l}\text { Premature } \\
\text { termination } \\
\text { codon }\end{array}$ & $\begin{array}{l}\text { Died of early } \\
\text { marrow } \\
\text { relapse (6) }\end{array}$ & $\begin{array}{l}X u \\
\text { et al(25) }\end{array}$ \\
\hline ML-DS23 & 24.8 & BM (75) & c. 89_149dup71 & p.Ser89Trp & Duplication & Splicing error & $\begin{array}{l}\text { Died of resistant } \\
\text { disease (5) }\end{array}$ & $\begin{array}{l}\text { Novel } \\
\text { mutation }\end{array}$ \\
\hline ML-DS24 & 5.0 & BM (54) & c. $220 G>A$ & p.Val74lle & Missense & Splicing error & CCR (26) & $\begin{array}{l}\text { Kanezaki } \\
\text { et al }\left.\right|^{(18)}\end{array}$ \\
\hline
\end{tabular}

Reference sequence: NG 008846.1. The first adenine of the initiation codon was assigned nucleotide + 1 (i.e. start site). BM: bone marrow; CCR: complete clinical remission; ML-DS: myeloid leukaemia of Down syndrome; NA: not available; PB: peripheral blood; TAM: transient abnormal myelopoiesis

46 (range 21-188) days. One child progressed to develop ML-DS 19 months after apparent remission at two months of age. The remaining seven children have maintained complete remission.

ML-DS was diagnosed at a median of 24 months of age. History of a preceding haematological disorder (two with TAM and six with myelodysplastic phase) was noted in 8 (33.3\%) children with ML-DS. Common presenting features included fever, pallor and bleeding. Two children presented with very high leucocyte counts $\left(\geq 100 \times 10^{9} / \mathrm{L}\right)$; none had central nervous system leukaemia. $22(91.7 \%)$ children with ML-DS received cytotoxic therapy. The estimated overall five-year survival rate of children with ML-DS was $58.3 \%$; nine children died, including three due to treatment toxicity (i.e. sepsis).
A total of 29 samples were analysed for GATA1 mutations; four samples did not have adequate material for analysis. GATA 1 exon 2 mutations were detected in $6(75.0 \%)$ of the eight TAM patients and 9 (42.9\%) of the $21 \mathrm{ML}-\mathrm{DS}$ patients (Table III). Wildtype exon 2 and 3 sequences were detected in the remainder. The bulk of the exon 2 mutations $(66.7 \%, n=10)$ were sequence deletions and insertions. The remaining five mutations were: missense mutations in three patients (1 TAM, 2 ML-DS), sequence replacement in one TAM patient and sequence duplication in one ML-DS. The majority of mutations resulted in premature sequence termination while the rest were associated with splicing errors during transcription. A majority of mutations (12 of $15,80.0 \%$ ) had not previously been reported. 
Table IV. Comparison of GATA1 mutation detection rate.

\begin{tabular}{|c|c|c|c|c|}
\hline Study & $\begin{array}{c}\text { PCR } \\
\text { amplification } \\
\text { exon }\end{array}$ & $\begin{array}{c}\text { No. of } \\
\text { patients }\end{array}$ & $\begin{array}{c}\text { No. of } \\
\text { mutations }\end{array}$ & $\begin{array}{c}\text { Mutation } \\
\text { (\%) }\end{array}$ \\
\hline Wechsler et $\mathrm{al}^{(21)}$ & $2,3,4,5,6$ & $6 \mathrm{ML}=\mathrm{DS}$ & 6 & 100.0 \\
\hline \multirow[t]{2}{*}{ Hitzler et al(22) } & 2 & 12 TAM & 9 & 75.0 \\
\hline & & $3 \mathrm{ML}=\mathrm{DS}$ & 3 & 100.0 \\
\hline \multirow[t]{2}{*}{ Rainis et $\mathrm{al}^{(13)}$} & 2 & $18 \mathrm{ML}-\mathrm{DS}$ & 17 & 94.4 \\
\hline & & 17 TAM & 16 & 94.1 \\
\hline \multirow[t]{2}{*}{ Groet et $\mathrm{al}^{(23)}$} & 2 & 10 TAM & 7 & 70.0 \\
\hline & & $6 \mathrm{ML}-\mathrm{DS}$ & 4 & 66.7 \\
\hline Mundschau et $\mathrm{al}^{(24)}$ & 2,3 & 7 TAM & 7 & 100.0 \\
\hline \multirow[t]{2}{*}{$\mathrm{Xu}$ et $\mathrm{al}^{(25)}$} & $2,3,4,5,6$ & 22 TAM & 21 & 95.5 \\
\hline & & $18 \mathrm{ML}-\mathrm{DS}$ & 12 & 66.7 \\
\hline \multirow[t]{2}{*}{ Ahmed et $\mathrm{al}^{(26)}$} & 2 & 4 TAM & 4 & 100.0 \\
\hline & & $12 \mathrm{ML}-\mathrm{DS}$ & 12 & 100.0 \\
\hline \multirow[t]{2}{*}{ Magalhães et $\mathrm{al}^{(27)}$} & 2,3 & 6 TAM & 4 & 66.7 \\
\hline & & $8 \mathrm{ML}=\mathrm{DS}$ & 6 & 75.0 \\
\hline \multirow[t]{2}{*}{ Cabelof et $\mathrm{al}^{(10)}$} & 2 & 5 TAM & 5 & 100.0 \\
\hline & & $14 \mathrm{ML}-\mathrm{DS}$ & 14 & 100.0 \\
\hline Kanezaki et al ${ }^{(18)}$ & $2,3,4,5,6$ & 78 TAM & 72 & 92.3 \\
\hline \multirow[t]{2}{*}{ Alford et al(16) } & - & 134 TAM & 118 & 88.1 \\
\hline & & 103 ML-DS & 88 & 85.4 \\
\hline \multirow[t]{2}{*}{ Present study } & 2,3 & 8 TAM & 6 & 75.0 \\
\hline & & $21 \mathrm{ML}-\mathrm{DS}$ & 9 & 42.9 \\
\hline
\end{tabular}

ML-DS: myeloid leukaemia of Down syndrome; PCR: polymerase chain reaction; TAM: transient abnormal myelopoiesis

\section{DISCUSSION}

This is the first report of GATA1 mutations in a cohort of Malaysian children with DS-associated myeloid disorders. Although the sample is small, truncating exon 2 GATA1 mutations were encountered in $75.0 \%$ of DS neonates who had TAM, a finding that mirrors published observations (Table IV). In contrast, GATA1 mutations were observed in less than half $(42.9 \%)$ of the children who had ML-DS. This low mutation detection rate is not readily attributable to poor PCR sensitivity, since the marrow blast burden (median $42 \%$, range $10 \%-75 \%$ ) was adequate in all cases. ${ }^{(16)}$ It is possible that a larger proportion of mutations in the ML-DS cohort occurred at genomic loci outside the primer binding sequence or at sites affecting primer annealing; gene sequencing might have uncovered these mutations.

All sequence variations in this study were described in accordance with the nomenclature recommendations of the HGVS. ${ }^{(17)}$ The majority of the exon 2 GATA1 mutations in our cohort were sequence deletions and insertions $(66.7 \%)$, resulting in frameshift errors and premature termination codons. No exon 3 mutations were identified. $80.0 \%(n=12)$ of observed mutations had not previously been reported and are likely to be novel. However, sequence variations in GATA1 have been inconsistently reported, making it difficult to evaluate GATA1 mutations in our series against those in the published literature. For instance, despite using the same GATA 1 reference sequence, Alford et al, who conducted the largest study of GATA 1 mutations in DS patients to date, unusually designated the first nucleotide of exon 1 as an indication of the start of the GATA1 sequence. ${ }^{(16)}$ Uniform reporting of sequence variations, in line with standard HGVS terminology, is expected to eliminate such discrepancies in future studies.

Lower relative quantitative expression of the truncated GATA1s protein has been reported to be associated with higher risk of progression to ML-DS. ${ }^{(18)}$ By contrast, the majority of mutations in our series are predicted to be associated with high protein expression of the truncated GATA1s protein (66.7\%). In the one patient with TAM who progressed to ML-DS, the mutation resulted in a splicing error predicted to be associated with high expression of GATA1s. High GATA1s expression is also predicted in six of nine mutation-positive ML-DS patients (66.7\%). These observations indicate continued uncertainty about the link between the type of GATA1 mutation in TAM and the risk of progression to ML-DS. ${ }^{(16)}$

Children with ML-DS have been shown to have a superior outcome when compared with children without DS who developed acute myeloid leukaemia (AML). Children with ML-DS experience event-free survival rates of more than $80 \%$ as compared with $30 \%-40 \%$ in non-DS children, particularly those with FAB-M7 subtype AML. ${ }^{(19)}$ It was proposed that GATA1 mutations may be important prognostic factors. Acquired GATA1 mutations are postulated to cause decreased transcription and expression of cytidine deaminase $(C D A)$ gene. CDA enzymes catalyse the deamination of cytosine arabinoside (ara-C) to its inactive derivative, ara- $U$. In the presence of GATA 1 mutations, there is a higher concentration of intracellular ara-C, leadings to an increase in cytotoxic efficacy. In our ML-DS cohort, the presence of GATA1 mutations may not necessarily confer a good prognosis. Four out of nine patients with GATA1 mutations developed relapse or resistant disease; one patient from the cohort with negative GATA1 mutation had relapse disease (Fig. 1). The patients with GATA1 mutations had higher disease-related mortality compared to those without $(80.0 \%$ vs. $50.0 \%$ ). CDA mRNA expression was measured using realtime quantitative PCR in two patients (ML-DS5 and ML-DS9) who had early bone marrow relapse, in order to study the relationship between GATA1 mutations and CDA mRNA. It was found that $C D A$ mRNA was upregulated in these two patients and was 40-fold higher compared to that of the other ML-DS cases, suggesting greater capability to metabolise ara-C. CDA mRNA expression in these two patients was, however, still lower than that in non-DS AML patients. ${ }^{(20)}$ Therefore, in the presence of GATA1 mutations, $C D A$ gene expression may be heterogeneous. Apart from the $C D A$ gene, GATA1 mutations may be associated with changes in the transactivational activity of many genes that influence treatment response.

Despite the limitations of sample size, our findings reiterate the observation of recurring GATA1 mutations in children with DS-related myeloid disorders. The high incidence of potentially novel GATA 1 mutations and the low frequency of such mutations in exons 2 and 3 raise the prospect of distinctive genomic events in our patient cohort. In our study, the mere presence 


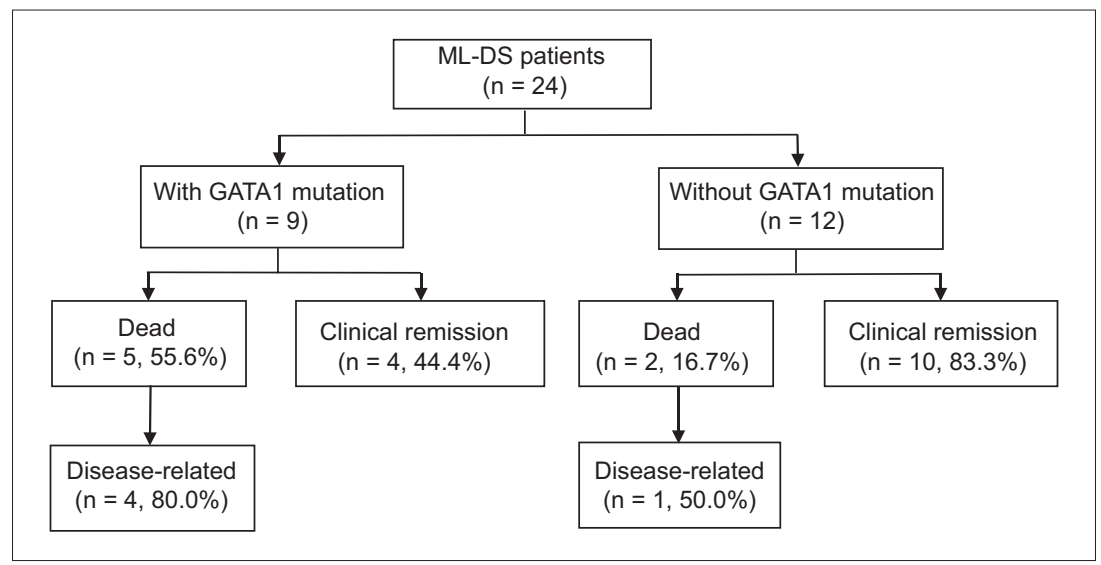

Fig. 1 Flowchart shows clinical outcome of children with myeloid leukaemia of Down syndrome (ML-DS). Of the 24 ML-DS patients, 21 had GATA1 analysis performed. 2 patients who died did not have GATA1 analysis performed.

of GATA1 mutations in ML-DS does not necessarily confer a good prognosis.

\section{REFERENCES}

1. Davidson MA. Primary care for children and adolescents with Down syndrome. Pediatr Clin North Am 2008; 55:1099-111, xi.

2. Lange B. The management of neoplastic disorders of haematopoiesis in children with Down's syndrome. Br J Haematol 2000; 110:512-24.

3. Seif AE. Pediatric leukemia predisposition syndromes: clues to understanding leukemogenesis. Cancer Genet 2011; 204:227-44.

4. Hasle H. Pattern of malignant disorders in individuals with Down's syndrome. Lancet Oncol 2001; 2:429-36.

5. Zipursky A. Transient leukaemia--a benign form of leukaemia in newborn infants with trisomy 21. Br J Haematol 2003; 120:930-8.

6. Gurbuxani S, Vyas P, Crispino JD. Recent insights into the mechanisms of myeloid leukemogenesis in Down syndrome. Blood 2004; 103:399-406.

7. Hitzler JK, Zipursky A. Origins of leukaemia in children with Down syndrome. Nat Rev Cancer 2005; 5:11-20.

8. Fonatsch C. The role of chromosome 21 in hematology and oncology. Genes Chromosomes Cancer 2010; 49:497-508.

9. Malinge S, Izraeli S, Crispino JD. Insights into the manifestations, outcomes, and mechanisms of leukemogenesis in Down syndrome. Blood 2009; 113:2619-28

10. Cabelof DC, Patel HV, Chen Q, et al. Mutational spectrum at GATA1 provides insights into mutagenesis and leukemogenesis in Down syndrome. Blood 2009; 114:2753-63.

11. Roy A, Roberts I, Norton A, Vyas P. Acute megakaryoblastic leukaemia (AMKL) and transient myeloproliferative disorder (TMD) in Down syndrome: a multi-step model of myeloid leukaemogenesis. Br J Haematol 2009; 147:3-12.

12. Roy A, Roberts I, Vyas P. Biology and management of transient abnormal myelopoiesis (TAM) in children with Down syndrome. Semin Fetal Neonatal Med 2012; 17:196-201.

13. Rainis L, Berchovich D, Strehl S, et al. Mutations in exon 2 of GATA1 are early events in megakaryocytic malignancies associated with trisomy 21. Blood 2003; 102:981-6.

14. Nichols KE, Crispino JD, Poncz M, et al. Familial dyserythropoietic anaemia and thrombocytopenia due to an inherited mutation in GATA1.
Nat Genet 2000; 24:266-70

15. Human Genome Variation Society. Nomenclature for the description of sequence variants. Available at: http://www.hgvs.org/mutnomen. Accessed August 25, 2012.

16. Alford KA, Reinhardt K, Garnett C, et al; International Myeloid LeukemiaDown Syndrome Study Group. Analysis of GATA1 mutations in Down syndrome transient myeloproliferative disorder and myeloid leukemia. Blood 2011; 118:2222-38.

17. Ogino S, Gulley ML, den Dunnen JT, Wilson RB; Association for Molecular Patholpogy Training and Education Committee. Standard mutations nomeclature in molecular diagnostics: practical and educational challenges. J Mol Diagn 2007; 9:1-6.

18. Kanezaki R, Toki T, Terui K, et al. Down syndrome and GATA1 mutations in transient abnormal myeloproliferative disorder: mutation classes correlate with progression to myeloid leukemia. Blood 2010; 116:4631-8.

19. Zwaan CM, Reinhardt D, Hitzler J, Vyas P. Acute leukemias in children with Down syndrome. Hematol Oncol Clin North Am 2010; 24:19-34.

20. Ariffin H, Garcia JC, Daud SS, et al. GATA1 mutations in patients with down syndrome and acute megakaryoblastic leukaemia do not always confer a good prognosis. Pediatr Blood Cancer 2009; 53:108-11.

21. Wechsler J, Greene M, McDevitt MA, et al. Acquired mutations in GATA1 in the megakaryoblastic leukemia of Down syndrome. Nat Genet 2002; 32:148-52.

22. Hitzler JK, Cheung J, Li Y, Scherer SW, Zipursky A. GATA1 mutations in transient leukemia and acute megakaryoblastic leukemia of Down syndrome. Blood 2003; 101:4301-4.

23. Groet J, McElwaine S, Spinelli M, et al. Acquired mutations in GATA1 in neonates with Down's syndrome with transient myeloid disorder. Lancet 2003; 361:1617-20.

24. Mundschau G, Gurbuxani, S, Gamis AS, et al. Mutagenesis of GATA1 is an initiating event in Down syndrome leukemogenesis. Blood 2003; 101:4298-300.

25. Xu G, Nagona M, Kanezaki R, et al. Frequent mutations in the GATA-1 gene in the transient myeloproliferative disorder of Down syndrome. Blood 2003; 102:2960-8.

26. Ahmed M, Sternberg A, Hall G, et al. Natural history of GATA1 mutations in Down syndrome. Blood 2004; 103:2480-9.

27. Magalhães IQ, Splendore A, Emerenciano M, et al. GATA1 mutations in acute leukemia in children with Down syndrome. Cancer Genet Cytogenet 2006; 166:112-6. 